\title{
NAAMGEVING IN INSULINDE,
}

\author{
DOOR
}

Dr. J. H. F. KOHLBRUGGE. 1

Het dragen van een naam is een der meest verspreide en oudste gebruiken onder menschen; ik achtte het belangrijk te onderzoeken hoe in Insulinde de naamgeving geschiedt, en of de daarbij bekende gebruiken wellicht eene verdeeling der volkeren in groepen zou veroorloven.

Hiervoor heb ik het onderwerp in eenige onderdeelen gesplitst, daar zoowel het aantal volkstammen als dat der bestaande gebruiken zeer groot bleek te zijn. In de eerste plaats wensch ik dan de vraag te beantwoorden:

Wanneer begint de menseh een nam te dragen? Voor alle volkeren geldt, dat dit reeds op zeer jeugdigen leeftijd geschiedt en wel dikwijls op vast bepaalde tijdstippen. Voor vele missen wij evenwel voldoende gegevens om na te gaan of de naamgeving aan bepaalde tijdstippen gebonden is, en slechts voor zeer weinige staat vast dat dit zeker niet het geval is.

$\mathrm{Bij}$ de Rotineezen ontvangt het kind wel eens een naam reeds vóór de geboorte om eene moeielijke bevalling te bespoedigen; men veronderstelt namelijk, dat het kind niet wil geboren worden omdat het nog geen naam heeft. Op de Sula-eilanden ontvangt het kind een naam voor men den navelstreng doorsnijdt. Van vele andere volkeren weten wij dat de naamgeving onmiddellijk na de geboorte plaats heeft, zoo bij. Rotineezen, Papua's van Kaimani, Kajan's, Tenggereezen (Java), en Alfoeren der Minahassa; bij de laatstgenoemden geschiedt dit overluid alsof men de sawangs (booze geesten) wil

1 In de navolgende beschrijving zijn de bronnen niet genoemd om niet telkens in herhalingen en verwijzingen te vallen; men vindt ze aan het slot, volgens de eilanden of eilandengroepen gerangschikt, waardoor dus direct blijkt op wiens gezag de meêgedeelde feiten berusten. Vele dank ik aan particuliere inlichtingen; ook de namen dezer deskundigen zijn bij de streken, waarop hunne mededeelingen betrekking hebben, genoemd. 
doen hooren, dat het kind bekend is bij goden en menschen en zij het dus niet zullen komen kwellen of dooden. Spoedig na de geboorte geschiedt dit ook bij de Toradja's van Parigi en Todjo (voor men het kind in de wieg legt).

De derde dag is de dag der naamgeving op Nias, waar men ook den naam aan de bevolking bekend makkt; den derden of vierden dag kiest men op Savoe. Andere tijdsbepalingen zijn : bij het ophouden der bloeding der moeder (Ambon), vóór het afvallen van den navelstreng (Kisser), bij het afvallen van den navelstreng (Aroe, Babar, Wetar), den vijfden dag op Java, op den tweeden of vijfden dag in de Loeang-Sermatagroep, op den eersten, derden, zevenden of tienden dag in Holontalo, den achtsten dag in de binnenlanden van Timor, den vierden of achtsten dag bij de Karau-Batak's, die evenwel somtijds langer wachten, den zevenden dag bij de Badoej's', na tien dagen te Boeool, na $8-10$ dagen bij de Papua's van Kaiser Wilhelmsland (N. Guinea). Minder bepaald is de tijd voor de namgeving aan de kust van Timor; men is vrij, mits het slechts binnen de 40 dagen geschiedt, die de vrouw gebruikt om uit te rusten en gedurende welke zij het huis niet verlaten mag. Ook de Boegineezen en Makassaren geven een naam of kort na de geboorte of na veertig dagen. In Mandeling wacht men veertien dagen tot eene maand, afhankelijk van den gezondheidstoestand der moeder en een door den datoe (priester) te bepalen gunstigen dag. Op Ceram benoemt men het kind na drie dagen of na eene maand, op de Serang-lao-eilanden na veertig dagen, op de Kei-eilanden den dertigsten dag, als de moeder in de rivier gebaad heeft.

Op Boeroe en Bali wacht men tot het kind drie maanden oud is. De mohammedaansche Taboengkoe (Centraal-Celebes) geven het kind een naam in de vierde maand van zijn leven. In Bolaäng Mongondou en op de Watoebellagroep geeft men een naam zoodra het kind lachen kan; bij de heidensche Tolalakis als het kind zitten kan; de Tomoris (ook in Centraal-Celebes) verklaren slechts dat het kind een naam moet hebben voor het zitten kan. In den Romangararchipel wacht men tot het kind gespeend is, omdat het dan den naam, die als een titel wordt beschouwd, dragen kan, en de Papua's (Noefoereezen) wachten meestal tot het kind loopen kan.

Al geven de Kajan's van Noord-Borneo meestal kort na de geboorte eenen naam, zoo kan het toch onbepaald uitgesteld worden als de voorteekens niet gunstig zijn. Het orakel, dat men hiervoor 
raadpleegt, is het kind zelf: men kittelt het met eene veer in den neus, niest het, dan kan men tot de naamgeving overgaan, niest het niet, dan wordt het onbepaald uitgesteld; het zoeken van een gunstigen dag komt trouwens ook bij andere volkeren voor (zie boven).

Geheel onverschillig voor den tijd van naamgeving zijn vele Toradja's in Centraal-Celebes. Zij haasten zich niet en wachten tot een toeval over den naam beslist, hetgeen ook wel eens direct na de geboorte geschieden kan. Ook de Alfoeren van Halmahera wachten soms langen tijd, en de Bataks van het Paneh- en Bilahstroomgebied doen 't zelfde. Om bijzondere redenen vermijdt het ook de Karau-Batak wel eens om aan het kind een naam te geven, en wel als vroeger geboren kinderen gestorven zijn. Vrienden en kennissen geven het dan meestal voorloopig eenen bijnaam, die later wel eens de blijvende naam wordt. In dezen zin, als voorbehoedmiddel tegen dood en ziekte, moeten wij ook het late naamgeven bij andere stammen verklaren, bijv. bij de Noefoereezen en de Alfoeren van Halmahera. Het is bij dezen moeielijk uit te maken of de naamgeving daar werkelijk zoolang uitgesteld wordt, dan of men slechts met het oog op de groote kindersterfte gedurende het eerste levensjaar, den naam vooreerst niet mag uitspreken. Bij de Dajaks van Noord-Borneo is het verboden den reeds gekozen naam uit te spreken, vóór het plechtige bad heeft plaats gehad dat aan de naamgeving vooraf moet gaan.

Heeft het kind eenen naam, dan is het met dezen en door dezen aan de booze geesten bekend; door het geen naam te geven of dien niet uit te spreken misleidt men die geesten en bewaart men de kinderen voor ziekte.

Deze opvatting, berustende op de meening dat ziekten, vooral die in het eerste levensjaar, aan geesten te wijten zijn, is in den Archipel zeer verbreid; wij komen daarop terug bij het bespreken der naamsveranderingen wegens ziekten of het verzwijgen van den naam, dien men zelf draagt. Dat voor deze volkeren de kindersterfte in het eerste levensjaar werkelijk zeer groot is, heb ik althans voor de gezonde en krachtige Tenggereezen aangetoond en zij is dus voor de andere zeer waarschijnlijk ${ }^{1}$.

Zoolang het kind geen naam heeft wordt het "kind, kleine,

\footnotetext{
${ }^{1}$ Die Krankheiten eines Bergvolkes der Insel Java. Janus 1897. S. 8. „59 pCt. der Todesfälle fallen anf das erste Lebensjahr".
} 
jongen of meisje" genoemd en zijn de volgende woorden gebruikelijk :

Mannelijke kinderen. Vrouwelijke kinderen.

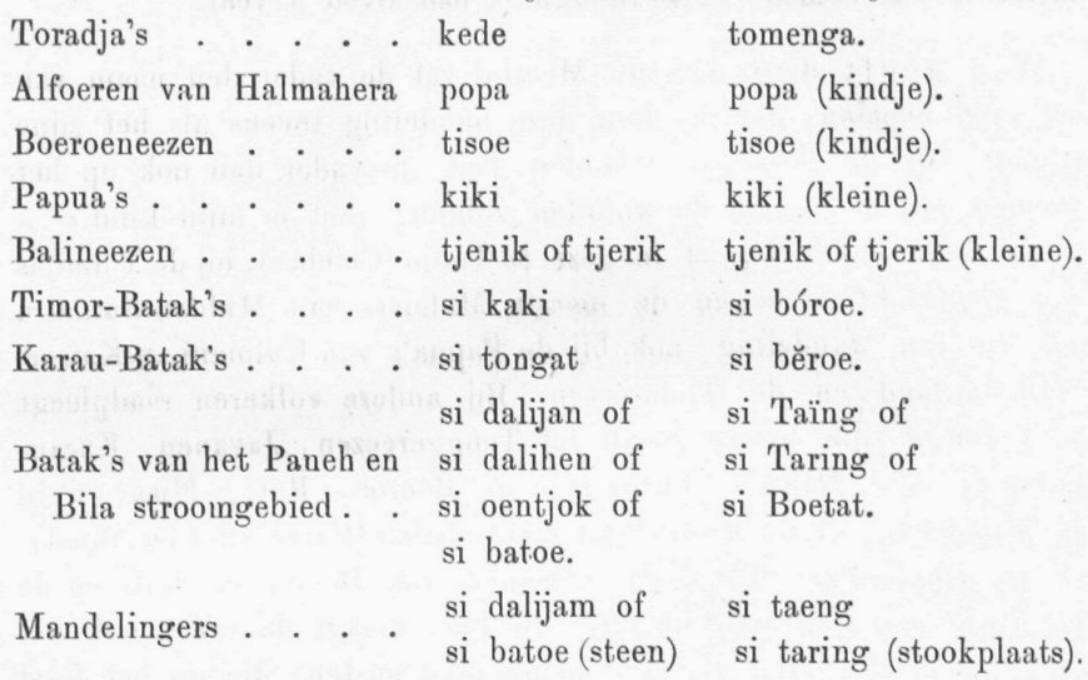

Uit het bovenstaande (ook uit de vrees voor naamgeving) blijkt wel voldoende dat de naamgeving bij deze volkeren aanduidt dat het kind een zelfstandig wezen geworden is; alleen wordt het begin der zelfstandigheid op zeer verschillende wijzen bepaald.

$\mathrm{Bij}$ het eene volk treedt de zelfstandigheid in, zoodra het kind van de placenta afgescheiden is, of men noemt den naam reeds voor men tot de doorsnijding overgaat; bij het andere volk begint de zelfstandigheid als de navelstreng afgevallen is en dus het laatste overblijfsel der vasthechting aan het moederlichaam verdwenen is, of als het kind het huis verlaten mag, wat dan meestal te samen valt met de reiniging der moeder ${ }^{1}$ of gepaard gaat met de eerste aanraking der aarde. Weer anderen beschouwen het kind eerst als een volkomen mensch als het lachen kan, of gespeend is, of loopen of zitten kan.

De naamgeving is dus eene erkenning der zelfstandigheid en door dien naam is het dan bij menschen, goden en geesten bekend, waarom de naam dan ook dikwijls overluid bekend wordt gemaakt.

Treffend zegt Furness van de Kajan's: Before the formal ceremony of naming a child for instance hàs been performed, the child has

\footnotetext{
1 De bovengenoemde dagen $5^{\text {de }}, 7^{\text {de }} 40^{\text {de }}$ enz., laten zich direct in verband brengen met: het ophouden der bloeding, het afvallen van den navelstreng, het ophouden der afscheiding (lochien) der moeder enz.
} 
no recognized place in the community and a mother in enumerating her childern would never think of mentioning one, that had died before it was named, even though it had lived a year.

Wie geeft den naam? Meestal zal de vader den naam van het kind bepalen, dat hij door deze handeling tevens als het zijne erkent. Op de Seranglao-eilanden laat de vader dan ook op het noemen van den naam de woorden volgen: "het is mijn kind."

De vader alléén beslist in deze te Todjo (Celebes), bij de Toradjas van Centraal-Celebes en de meeste Maleiers van Midden-Sumatra ook die van Mandeling; ook bij de Papua's van Kaimani en KaiserWilhelmsland en de Timoreezen. Bij andere volkeren raadpleegt de vader òf zijne vrouw zooals bij Tenggereezen, Javanen, KarauBatak's, vele Dajak's (Furness), op Boeroe, Roti, Nias en in de Minahassa, ò de mannelijke familieleden (Batak's der Oostkusi), of de grootouders (Toradja's, bewoners van Boeroe en Roti en de Tolalakis van Centraal-Celebes). Op Java vraagt de vader ook wel eens de goedkeuring van alle mannelijke gasten, die op het feest der naamgeving gekomen zijn, hetgeen evenwel meer eene beleefdheid is, of hij raadpleegt den Mohammedaanschen priester, hetgeen ook in Todjo geschiedt. Bij de Badoej's geeft de poe-oen (priester) op verzoek der ouders den naam.

Andere volkeren laten het naamgeven geheel aan de grootouders over (Parigi, Talauer, Papuas van Noefoer), zoo deze nog leven; of aan de moeder (Halmahera, Watubela-eilanden); of de vader geeft namen aan de zoons, de moeder aai de dochters (Ceram, Tanembar, Timorlao-eilanden) ${ }^{1}$ waarbij de vader door zijn broeder, de moeder door hare zuster vervangen kan worden (Loeang-Sermatagroep.)

In Isebong (midden-Sumatra) wordt de naam door de grootmoeder, door eene oudere tante, of door de moeder bepaald. Ook komt het voor dat de naamgeving geheel aan de familieleden is overgelaten (Kei-eilanders, Boegi's), waarbij de ouders uitdrukkelijk kunnen worden buitengesloten, daar anders het kind ziek zou worden (Wettar). Bij de Karau-Batak's heeft de vader alleen op den naam van het eerste kind geenen invloed, want zoo dit een jongen is, ontvangt het zijnen naam van de moeder (Kalin boeboe) of van den broeder der moeder of diens vrouw (de mami van den kleine). Is het een meisje dan geeft de bibi (tante van vaderskant) het een naam ${ }^{2}$.

1 Een dergelijk gebruik vindt men ook op de Talauer (zie beneden).

${ }^{2}$ Een dergelijk gebruik vindt men bij de Tenggereezen (zie beneden). 6. Volgr. VIII. 
Bij eenige volkeren vindt men een peetvader, zoo op Savoe waar de ama hopo, die den naam geeft, ook het kind aanneemt, als de ouders mochten sterven. Bij de Dajak's wordt door het lot een peetoom bepaald, dien men den tweeden vader van het kind noemt. Hij moet het petekind af en toe bezoeken, en als het ouder geworden is op toewak tracteeren.

Bij de Toradja's komt het ook wel voor dat men een vreemdeling van aanzien verzoekt den naam van het kind te bepalen.

Zeer veel treft men ook het gebruik aan om den nam door een orakel of door het lot te doen bepalen.

De Dajak's van Z.-O. Borneo vullen op den dag van het geboortefeest eene kom met ongekookte rijst; zeven der oudste mannelijke ongehuwde bloedverwanten snijden ieder een stokje rotan van ongeveer een palm lengte en planten dat recht overeind in de kom met rijst. Aan ieder der zeven stokjes wordt door zijn eigenaar een naam gegeven. Vervolgens gaat de oudste der genoodigden mits geen familielid zijnde - met die kom naar binnen bij de moeder van het kind; deze grijpt op goed geluk af een dier stokjes, en de zuigeling ontvangt nu den naam, dien men aan het stokje gegeven had. Hij, die aan dat stokje den naam gaf, is nu de tweede vader van het kind.

In Boeool schrijft de Kasisi drie namen op drie stukken papier en laat een daarvan door de moeder trekken. Op Bali neemt de priester een stuk lontarblad en schrijft daarop namen in verschillende richtingen, meestal de eerste de beste. Daarna hecht hij aan het lontarblad een stukje katoen vast, dat hij aansteekt en zoolang laat branden, totdat de lontar op den grond valt. Is dit geschied, dan bukt hij zich en onderzoekt nu welke naam rechts of links het dichtst bij of het verst af (al naargelang men vooraf bepaald heeft) van hem gelegen is. Deze naam is dan door de goden bepaald.

Eene andere wijze van loting is gebruikelijk op de Sula-eilanden, Ambon, Babar, Kisar en Aroe. De Duduku noemt eenen naam op Sula en vraagt het kind of het dien dragen wil. Schreeuwt het, dan is dit een bevestigend antwoord, zoo niet dan noemt men andere namen tot het kind antwoord gegeven heeft. Op Ambon en Aroe houdt men het kind voor de borst der moeder, de vader noemt achtereenvolgens eenige namen, de naam die genoemd werd op 't oogenblik dat het kind den tepel nam, blijft de naam van het kind; op Babar en Kisar is dit gebruik slechts eenigszins gewijzigd, in zoo verre dat men op Babar het kind voor de borst 
eener vreemde, vrouw houdt, en op beide eilanden de vader er niets mee te maken heeft. Op de Luang Sermatagroep verandert men den reeds gekozen naam als het kind bij de naamgeving schreit, tot dit niet meer geschiedt. Deze gebruiken toonen duidelijk hoe zeer voor deze volkeren zelfstandigheid en naamgeving gelijksoortige begrippen zijn, zooals wij boven reeds hebben niteengezet.

Elders tracht men door een orakel zekerheid te krijgen dat de reeds gekozen naam goed is, en wel gaat men te werk als volgt.

De Kajan's (Furness) nemen het stuk rotan, dat men gebruikt heeft om het heilige vuur aan te leggen en buigen dit zoo dat de uiteinden elkander raken. $\mathrm{Nu}$ lat men de buiging wegbranden en past de beide stukken tegen elkander. Is het eene langer dan het andere, dan is de gekozene naam hierdoor goedgekeurd; zijn beide stukken van gelijke lengte, dan moet een andere naam gezocht worden.

Op Ceram raadpleegt men eene pinang, door die in tweëen te splijten en te kauwen; blijkt het dat het inwendige der schil rood is, dan is dit een slecht omen; of men splijt eene kalapanoot, laat de stukken vallen, en let er op hoe die vallen. Het laatstgenoemde orakel gebruiken ook de Kei-eilanders. Deze leggen de beide helften in eene wan, daarna bidt een der oudste bloedverwanten: Heer zon, vrouw maan, geesten der voorvaderen, vestigt uwe aandacht op deze kalapa", of "op deze ubis" als men twee ubis gebruikt. Voorts makt men eene beweging met de wan dat de stukken (of de ubis) neervallen; vallen beide zijden open, dan is dit op Kei een slecht teeken op Ceram een goed teeken; valt de rechterhelft open en de linkerhelft dicht, dan is zulks op beide eilanden een goed teeken. Vallen beide met de bolle zijde naar boven, dan is dit op Kei een bewijs, dat de gekozen naam goed is. Zoo het orakel ongunstig was, dan kiest men eenen anderen naam en raadpleegt nu weder het orakel met eene nieuwe vrucht, tot het antwoord gunstig is.

Ook bij de Batak wenscht men zekerheid of de gekozen naam goed is, hiervoor neemt de tante van moederskant eenige rijstkorrels, en legt die in de linkerhand van de bibi (tante van vaderskant). $\mathrm{Nu}$ wordea deze rijstkorrels geteld ; vormen zij een oneven getal, dan is de zaak in orde. Dan legt men eenige korrels in de rechterhand; vormen deze een even getal, dan is daarmede uitgemakt dat de naaın bij het kind past. Die wordt dan aan het kind bekend gemakt met de vermaning niet ziek te worden. 
Soms kan het met dit orakel lang duren voor een goede naam gevonden is, tenzij eene handige tante de korrels even of oneven weet te maken.

Ook bij de Rotineezen komt het wel eens voor dat men een orakel raadpleegt en wel bij eene moeielijke bevalling. Dan laat de vroedvrouw de familieleden bijeenroepen en deelt hun mede, dat het kind niet wil geboren worden omdat het geen naam heeft. Wordt de baring, na de nu plaats hebbende keus van een naam, niet bespoedigd, en is het leven der moeder in gevaar, dan neemt de Rotinees zijn toevlucht tot het oekoer sekai (het meten met de lans), waardoor de geesten der voorouders (nitoe) geraadpleegd worden. Vader of oom, of wie ook, neemt eene lans en steekt de punt daar. van in de deurpost aan den ingang van het huis. Nu vademt men de lans met uitgestrekte armen en noemt den naam van een der voorvaderen. Zoo de lansvademer met zijn middenvinger niet kan reiken tot aan de punt van de lans, die in de deurpost gestoken is, dan is dat een teeken, dat de nitoe niet instemmen met den naam, die genoemd werd. Men gaat voort op deze wijze met het bevademen der lans, tot men, bij het noemen der namen eensklaps, met den arm vergenoeg reiken kan en de deurpost wel aanraakt. Hierdoor weet men dan zeker dat die naam door de nitoe is aangewezen en ook gewenscht door het kind ${ }^{1}$.

Waardoor wordt de keus van den naam bepaald? Dikwijls door de namen der voorouders, zooals op Roti. Vooral wanneer de vader of een der grootouders gedurende de zwangerschap stierf, zal men aan het kind den naam des (of der) overledenen geven. Ook op Flores verkiest men de namen van ouders en grootouders, eveneens op Savoe. Nog levende grootouders vernoemt men wel eens op Java, en wel ontvangt dan de kleinzoon den kindernaam des grootvaders, geldt het een meisje, dan den kindernaam der grootmoeder; ook op Gorontalo vernoemt men wel eens de nog levende grootouders en de Papua's van Kaiser-Wilhelmsland noemen een jongen naar den vader, een meisje naar de moeder als de gelijkenis groot is, ook noemt de vader zijn kind wel naar zijn besten vriend. Dit zijn evenwel uitzonderingen, als regel geldt dat grootouders slechts dan vernoemd worden als zij overleden zijn, levenden te vernoemen zou hun leven in gevaar brengen.

1 Ook op Ceram is het meten 'van een stok „haikalipa" of „nauwa loha katou hata" als orakel bekend. 
De Toradja`s, de Papua's en de Talaureezen kiezen wel eens den naam van een overleden familielid opdat men door den voortlevenden naam den overledene niet zou vergeten; de Toboengkoe (CentraalCelebes) mogen slechts de namen der overgrootouders aan de kinderen geven. De Talaureezen zullen voor mannelijke kinderen slechts de namen van mannelijke voorouders kiezen en voor meisjes die der vrouwelijke. Ook op Timor en bij de Boegi's worden voorouders wel eens vernoemd.

Daarentegen is het op het eiland Boeroe, Halmahera en in de Minahassa, en ook bij de Batak's streng verboden voorouders of overleden familieleden te vernoemen. Men vermijdt dit ook om deze reden, dat ouders dan de namen hunner kinderen niet zouden mogen uitspreken en ook de zusters en broeders van het kind dien naam niet zouden mogen noemen, daar de namen der ouders en oudere broeders en zusters pĕmali zijn, evenals de naam van een meerdere pĕmali is voor een mindere.

Zonder dat de ouders hunne namen aan de kinderen geven kunnen de namen der ouders toch invloed hebben op dien des kinderen. Zoo bestaan vele namen op Java uit twee deelen, twee gecombineerde kawiwoorden, wier verbinding dikwijls geheel willekeurig en zinloos is. Het eerste woord is als het ware de stam, men wijzigt slechts het tweede gedeelte en verkrijgt zoo eenen naam voor zijn kind, die dus ten deele met den vadersnaam overeenstemt. Daarom zal men in ééne dessa slechts een Parwirioredjo vinden, maar velen wier naam met Parwirio begint met zeer verschillende achtervoegsels als: sentono, diwirjo, disastro, dimedjo, taroeno, endjojo, kromo, widjojo, mengålå, drånå, setjo en anderen ; daarentegen kunnen de stamwoorden Karto, Dermo en anderen, weder varieeren door al de bovengenoemde achtervoegsels dus: Kartoredjo, Kartosentono, Dermoredjo enz.

De Boegi's geven dikwijls namen, die naar hun beteekenis synoniem zijn met dien der moeder. Bij de Batak's hebben wel eens alle kinderen uit één huisgezin synonieme of gelijksoortige namen, zooals: boom, stam, tak, blad.

Een zeer eigenaardig gebruik bestat bij de Tenggereezen om de nạmen der ouders pasklaar te maken voor de kinderen, vooral voor de eerstgeboren kinderen. Den eersten zoon noemt men naar de moeder, de eerste dochter naar den vader, waarbij de naam, namelijk diens eindlettergreep, gewijzigd wordt, waardoor hij respectievelijk meer mannelijk of meer vrouwelijk klinkt. 


\begin{tabular}{|c|c|c|c|c|c|}
\hline $\mathrm{De}$ & dochter & $\operatorname{van}$ & Amir & heet & Amidah. \\
\hline "I & $" \prime$ & $" \prime$ & Doer & " & Doerimah. \\
\hline & " & " & Giso & " & Gisah. \\
\hline & " & " & Garmo & " & Garsi. \\
\hline 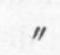 & zoon & " & Djah & " & Djahiman. \\
\hline 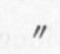 & " & $"$ & Djimah & " & Djimo. \\
\hline 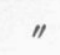 & " & $"$ & Warsinten & " & Warso. \\
\hline & " & " & Kasirah & " & Kasiroen. \\
\hline
\end{tabular}

Nog sterker zijn de volgende wijzigingen, waarbij slechts de eerste twee letters der namen behouden blijven.

$\begin{array}{llll}\text { Alinodin wordt } & \text { Alimah. } & \text { Ratni wordt Raiman } \\ \text { Gadri " } & \text { Gami. } & \text { Dasinten " } & \text { Darmin. } \\ \text { Batmo " } & \text { Basinah. } & & \end{array}$

Soms blijft slechts de beginletter onveranderd.

$\begin{array}{llll}\text { Boeroen wordt Bajinah. } & \text { Dasilah wordt Djaimin. } \\ \text { Adoen " Amoenah. } & \text { Roepiah " } & \text { Radio. } \\ \text { Aiman. " Anti. } & \text { Pina " Paiman. } \\ \text { Ganawi " Gimoek. Ansirah " Adin. } & \text { Amirah " Andarmo. }\end{array}$

Verder gaat de wijziging niet; de eerste letter blijft steeds dezelfde; elk familievader verzint deze wijzigingen zelf. Soms noemt men meerdere kinderen naar een der ouders en kan een vader Namin twee dochters hebben, de eene Naimi, de andere Nainten.

Uit het bovenstaande mag men evenwel volstrekt niet afleiden, dat alle genoemde volkeren bij voorkeur voor hun kinderen de namen van ouders en grootouders gebruiken; dit mag slechts voor enkelen beweerd worden, als Rotineezen en Savoeneezen, bij de audere volkeren doen zich bij de naamgeving tal van andere invloeden veel sterker gelden.

Zeer groot is vooral de invloed van gebeurtenissen, die gedurende de bevalling of zwangerschap plaats grepen, hetzij zij deze direct influenceerden of verwijderd plaatsgrepen, maar toch betrekking hadden op het familieleven. Zoo noemt men op Halmahera het kind naar de laatste handeling der moeder voor de bevalling, of naar het laatste voorwerp dat zij hanteerde, of naar het werk dat den vader bezig hield, of de plaats waar de vader vertoefde. Ook krijgt het kind wel eens den naam van een belangrijk voorwerp, dat men kort van te voren kocht of verkregen heeft, naar het 
bezoek van een voornaam persoon, de vruchten, die juist geoogst werden, eene aardbeving, die plaats greep enz.

Dikwijls drukken namen ook de vreugde of het gevoel der onders uit: "de verlangde, de begeerde, de verwachte" zijn welbekende namen onder Bataks en de Maleiers van Midden-Sumatra.

Dezelfde gebruiken vindt men bij de bewoners van de Minahassa, Boeroe, van de Papua-landen, bij de Timoreezen, Boegi's, KarauBatak's, Javanen.

Ook kan de nam bepaald worden door de lichaamshoedanigheden, in ' $t$ ' oogloopende kenmerken, of de gebreken van een kind. De naam duidt dan niet altijd de hoedanigheid zelf aan, maar een dier, dat die eigenschap in sterke mate bezit, dus met sarcasme of spot, als bij de Toradja's, ook op Boeroe, bijv. "weenend als een varken". Ook op Roti, Timor, in de Minahassa, bij de Boegi's, Karau Batak's, de Papua's van Kaiser Wilhelmsland en de Maleiers van Midden-Sumatra kan men hetzelfde opmerken.

Sommige volkeren schrikken er niet voor terug triviale, obscene namen te geven, zooals de woorden, die geslachtsdeelen aanduiden ('Toradja, Javanen enz.), anderen verkiezen zelfs zulke platte namen met leelijke, vieze, onkiesche beteekenis. De bewoners van Nias meenen dat fraaie namen ziekten berokkenen, en daar deze op later leeftijd minder gevreesd worden, verandert men dan die namen in beter klinkende of ruilt ze tegen namen met schoonere beteekenis. Een schoone of grootsche naam is ook op Halmahera ongeluk brengende, "panas" 1 .

Namen met mooie beteekenis treft men dikwijls bij meisjes in Midden-Sumatra (zie beneden).

Namen, die goede eigenschappen aanduiden, zijn niet alleen op Nias gewild, maar ook in de Minahassa, dikwijls omdat de vader meent die hoedanigheid zelf te bezitten. De Dajak kiest gaarne de namen van rijke menschen, of van hen, die een hoogen leeftijd bereikt hebben of titels van Europeanen. Ook de Boegi's kiezen gaarne namen van hoofden of rijke menschen. Daarentegen mag de bewoner van Bolaäng Mongondou de namen van vorsten of personen van koninklijken bloede niet gebruiken, ook de Karau-Batak laat de mooie en hoogdravende namen aan vorsten en priesters over ${ }^{2}$.

1 Dergelijk bijgeloof komt ook in Europa voor.

${ }^{2}$ Vroeger, ten deele nog heden, kende men in Europa (vooral in Duitschland) vele voornamen, die alleen door aanzienlijken gebruikt werden. 
Namen, overeenstemmende met den weekdag of maand der geboorte, hoort men bij Tenggereezen, Javanen en Gorontaleezen '.

Bij de Toradja's en op Boeroe en in Bolaäng Mongondou hoort men dikwijls als personennamen de namen van rivieren, dorpen bergen, boomen, planten, vruchten en dieren; de Papua's der Geelvinkbaai verkiezen plaatsnamen en vogelnamen, vooral den naam van den arend (mangangan), nooit die van bloemen of voorwerpen, die van Kaiser Wilhelmland noemen naar allerlei dieren of planten. De Rotineezen en Timoreezen noemen hun kinderen naar hemellichamen, windstreken, vruchten; ook gebruiken zij werkwoorden, die eene handeling aanduiden als namen, evenals voorwerpen en metalen. De Dajak kiest voor jongens meestal de namen van dieren, voor meisjes die van bloemen en sterren, verder hoort men er de namen van metalen en Hollandsche stoomschepen.

De variatie is dus onbeperkt, vooral ook onder de Bataks, wier namen kunnen zijn: zelfstaudige naamwoorden, bijvoegelijke naamwoorden, voornaamwoorden, telwoorden, werkwoorden, voegwoorden, bijwoorden enz., soms samenstellingen, soms een geheele zin. Eene eigenaardige beperking legt de Batak zich evenwel op door de bepaling: dat de naam evenveel medeklinkers moet hebben als de naam van den geboortedag.

Uit het voorafgaande blijkt ook reeds voldoende, dat alle genoemde volkeren de beteekenis hunner namen zeer wel kennen, het zijn (evenals vroeger in Europa) gewone woorden hunner taal, of samengestelde woorden of korte volzinnen. Waar de beteekenis der namen niet meer verstaan wordt, daar is dit aan vreemden invloed of aan wijziging der taal toe te schrijven, evenals in Europa ${ }^{2}$. De Toradja, die den naam van een vreemdeling kiest, de Dajak, die zijn kind naar eene stoomboot doopt, de Alfoer, die christelijke namen overneemt en allen, die namen nit den Koran verkiezen, wat zeer veel voorkomt, verstaan natuurlijk de beteekenis dezer namen niet. Op Savoe slechts; waar elk aanzienlijk inlander een

1 Sylvester in Duitschland voor kinderen, die op dien dag geboren werden en de namen der heiligen, die bij de geboortedagen behooren.

2 Toch kennen vele Europeanen de beteekenis der namen, die zij aan hunne kinderen geven, en soms heeft die beteekenis ter dege invloed op de keus gehad. Ook het noemen van kinderen naar gebeurtenissen treft men onder Europeanen; een bekend voorbeeld is: Maria Tesselschade, waar de naam het verlies van een schip haars vaders aanduidt; ook Lucipara, de naam van een der dochters van generaal De Stuers, geboren na de schipbreuk op een der Luciparaeilanden in Mei 1837. 
langen stamboom heeft, is de beteekenis van vele oude namen verloren gegaan, evenals bij ons, al moge de taalgeleerde in staat zijn die terug te vinden. Hetzelfde geldt van Java, waar vele namen kawiwoorden zijn, welke heilige taal door ongeletterden niet meer verstaan wordt.

$\mathrm{Bij}$ geen volk is de beteekenis der namen zoo geheel verloren gegaan als bij de Tenggereezen. Oorspronkelijk waren hunne namen oud-Javaansche, door de opzettelijke en geheel vrije wijziging van deze hebben zij alle beteekenis verloren en worden dagelijks nieuwe namen verzonnen, hun aantal is dan ook onbeperkt groot; ik verzamelde eens 800 in eenige weken tijds en had mijne lijst wel tot duizenden kunnen uitbreiden. In Europa kent men trouwens ook zulke wijzigingen en dikwijls met hetzelfde doel verzonnen: om eenen mannennaam in een vrouwennaam te veranderen of omgekeerd.

Dit gebruik veronderstelt natuurlijk dat er een verschil bestaat tusschen namen van vrouwen en die van mannen, zooals dit bij ons en ook op Java gebruikelijk is. Het onderscheid ligt óf in de beteekenis, óf in den klank, óf berust eenvoudig op gewoonte; toch treft men ook onder Javanen wel namen aan, die zoowel voor jongens als voor meisjes gebruikt worden. De Tenggereezen onderscheiden de namen naar de eindlettergrepen, maar ook zij hebben bij het onbegrensd variatievermogen hunner namen, vele, waarvan zij niet weten, of zij door mannen of door vrouwen gedragen moeten worden. Ook de Savoeneezen kennen verschillen voor de namen der beide geslachten, slechts weinige namen worden voor beide geslachten gebruikt.

De meeste andere volkeren kennen dit onderscheid niet, zoo de Toradja's van Posso en Parigi, de Alfoeren van Halmahera en Boeroe, de Rotineezen, Timoreezen en de Dajak's. Toch makt de bewoner van Boeroe in zooverre een onderscheid, dat hị voor den naam, die eene vrouw aanduidt het prefix Moeka of Tina plaatst en verder gaarne namen van dingen kiest, die voor hem vrouwelijk zijn, als maan en bloem, terwijl namen aan dieren ontleend steeds mannen schijnen aan te duiden.

Op Halmahera plaatst men "Ngo" voor het woord, dat als vrouwennanm wordt gebezigd. De Dajak stemt daarin met den bewoner van Boeroe overeen, dat hij aan meisjes liefst namen van bloemen geeft, aan jongens, die van dieren; maar dit is volstrekt geen vaststaande regel. De Papua (Noefoereezen) maken volgens van 
Hasselt verschil tusschen vrouwen- en mannennamen, maar hij deelde niet mede, waarin dit versehil bestaat ${ }^{1}$.

Wilken vermeldt dat de Maleiers der Padangsche bovenlanden zich er op toeleggen welluidende namen voor meisjes te bedenken als: Si Sari-ati = de hartebloem, Si Reno-ati $=$ het schoone hart, Si intan urai $=$ het zuivere juweel, enz.

Laten wij thans nog nagaan of de beteekenis der namen ook eene voorspellende kan zijn of eenen wensch te kennen geeft.

Boven heb ik er reeds op gewezen dat de bewoners van Nias, die der Minahassa, de Dajak's en Boegi's gaarne namen geven met eene goede beteekenis, of die van rijke en machtige lieden, of van menschen, die eenen hoogen ouderdom bereikten; zij houden zulke namen voor gelukbrengend, geven ze dus met eenig bijgeloof. Pleyte zegt van de bewoners der Kei-eilanden, dat het hun er zeer om te doen is eenen gelukaaubrengenden naam te bedenken, maar het komi mij voor dat dit slechts slaat op het raadplegen van een orakel; niet op de goede beteekenis van het woord, dat als naam dienst moet doen.

Ook de Batak's (vooral vorsten en priesters), geven wel eens mooie namen, in de hoop dat de kinderen later aan de beteekenis van dien naam zullen beantwoorden. Zulke namen zijn voorspellende of verwachtende. De kleine man onder de Bataks zal een mager en ziekelijk kind ook wel Si Bolat (dik) noemen in de hoop dat het dik en vet moge worden. Waarschijnlijk geschiedt ook dit om de geesten door dien naam te misleiden. Zijn er evenwel in een huisgezin kinderen met mooie namen gestorven, dan geeft men aan een volgend kind een minder mooien naam. Daarin ligt dus, evenals bij die volkeren, die bij voorkeur of uit vrees leelijke namen geven, eene erkenning dat de nam terdege invloed op de toekomst van het kind heeft. Er zijn evenwel volkeren, die geen begrip hebben van de mogelijkheid van dergelijken invloed zooals de Tenggereezen, Rotineezen en Toradja's ${ }^{2}$.

Andere eilanders kennen wel mooie en leelijke namen, maar geen goede of slechte (Java); sommigen zijn daarbij zoo onverschillig, dat zij, (alhoewel zij geen angst voor mooie namen hebben) hun kinderen namen geven als: varken, hond, wandluis, kippendrek, leelijkert (Boeroe).

1 De Papua's van Bogadjim maken geen versehil tnsschen mannelijke en vrouwelijke namen, die van Finschhafen wel (Hagen).

${ }^{2}$ In Europa is dit bijgeloof ter dege bekend. 
Van veel meer beteekenis dan de naam is voor de toekomst van het kind de tijd waarop het geboren werd. Dit geldt ook voor Java, waar bijv. de Woekoe Sinto slecht is voor de geboorte, een in die woekoe geboren kind zal spoedig sterven en zullen de ouders daarom zulk een kind gaarne weggeven. Nog veel meer wordt hierop door de Karau-Batak's gelet; voor hen heeft bij de geboorte bijna elke dag, ja bijna elk uur zijne bijzondere beteekenis voor de toekomst van het kind '.

Wij moeten uu nog de vraag beantwoorden: Is het Europeesche gebruik om meer dan een naam aan een kind te geven ook in Insulinde bekend?

Dat vele namen uit samengestelde woorden bestaan werd boven reeds gemeld; vooral de mooie, uit de Kawitaal afgeleide namen op Java zijn samenstellingen, maar ook de Papua houdt daarvan; de Batak niet minder, een geheele volzin kan bij hem naam worden. Twee namen, die geheel zelfstandig naast elkander staan kent men slechts op Roti, waar men wel eens twee namen van voorouders aan één kind geeft.

Bijnamen, die aan een tweeden naam doen denken, komen meer voor. Op Engano voeren de broeders en zusters na het overiijden van een jonger broertje of zusje den bijnaam Kenoekoe, na het overlijden van een volwassen broer of zuster "na-ija", na het overlijden van vader of moeder "ka howka"; een man voegt bij het overlijden van een vriend het woord "na-noah" bij zijnen naam, en na den dood der vrouw het woord "Koelija." Op Bali hebben vele kinderen bijnamen, die hunne volgorde of eventueele eerstgeboorte onder broeders en zusters aanwijzen. De Batak's gebruiken bijnamen bij het zangspel der jonge lieden.

Familienamen in onzen zin komen niet voor tenzij zij, zooals in de Minahassa, tegelijk met het christelijk geloof werden ingevoerd ${ }^{2}$.

Wel zijn eenige volkeren in stammen verdeeld (zooals de Joden) en weet iedereen den naam van zijnen stam (marga) of onderdeel van dien stam (Enganeezen, Batak's, Maleiers van Midden-Sumatra), die wel eens ter verduidelijking achter den eigen naam gevoegd wordt: Op de eilanden Roti, Savoe en Timor heerscht het gebruik dat. de vaders- of grootvadersnaam als "van" gebruikt wordt. Op

${ }^{1}$ Nadere opgaven vindt men in: Mededeel. v. h. Nederl. Zend. Gen.; het doet ons denken aan de horoscopen der sterrenwichelaars.

${ }^{2}$ Familienamen zijn ook bij ons eerst in deze eeuw algemeen geworden, zij waren in de middeleeuwen slechts onder hooggeplaatsten bekend. 
Rotti en Timor is de naam van den grootvader de "van" van het kleinkind. Heet bijv. de jongen Koan, diens grootvader Tanggi, dan wordt die jongen Koan Tanggi genoemd, terwijl de vader bijv. Daë heet. Hierdoor kunnen zij hunne lange stamboomen ook beter onthouden. Op Savoe is bij wettige kinderen de vadersnaam "van", bij onwettige de moedersnaam (evenals in Europa), ook zij hebben eeuwenoude stamboomen.

Vele Europeesche familienamen zijn op gelijke wijze ontstaan. .

Op Savoe wordt wel eens de naam van een bloedverwant boven dien van den vader als "van" verkozen. Dit geschiedt als de voorafgaande kinderen stierven; door het nieuw geboren kind op eens andermans naam te zetten hoopt men het te behouden. Dit gebruik sluit aan bij een ander "het verwisselen der namen", dat wij later zullen bespreken.

Plechtigheden bij de namgeving. Bij vele volkeren gaat de naamgeving met eenige plechtigheden gepaard, waarvan ik than zal trachten, een overzicht te geven.

In de eerste plaats moet een geschikte dag gekozen worden, als de dag niet door vaste regelen bepaald is. Dit kiezen van een gunstigen dag geschiedt bij de Karau-Batak's, Mandelingers en Timoreezen.

Het voornaamste is verder natuurlijk de feestmaaltijd, die bijna overal gevonden wordt behalve op Halmahera, Boeroe, in Balaäng Mongondou en bij de Tenggereezen. Soms is het feest grooter bij eerstgeboren kinderen (Mandeling).

Op vele eilanden van den Archipel bestaat daarnaast de gewoonte een bepaald dier voor het feest te slachten, meestal een varken (Timor, Savoe, Minahassa, Nias, Borneo). Een arme Dajak neemt in plaats van een varken wel eens eene kip, te Holontalo worden voor de naamgeving van een jongen twee bokken geslacht, voor die van een meisje eene geit. Op Boeroe neemt men steeds eene geit. Het vleesch of bloed dezer dieren wordt meestal in betrekking tot het kind gebracht, en wel of door de toekomst van het kind uit de harten der dieren te voorspellen (Minahassa) óf door het kind met het vleesch of bloed der dieren aan te raken. Zoo was het vroeger in de Minahassa gebruikelijk, het ceremonieel eerst toe te passen als het kind reeds twee of drie maanden oud was; op sommige plaatsen bestond din de plechtigheid hierin, dat de priester of walian een weinig rijst en varkensvleesch tusschen duim en wijsvinger nam en dat in den mond van het kind duwde, terwijl hij den 
naam noemde. $\mathrm{B} \ddot{i j}$ de Toumpakĕwa doopt de walian den wijsvinger in het bloed van een varken en, terwijl hij het voorhoofd van het kind daarmee bestrijkt, noemt hij den naam van het kind, dien de ouders bepaald hebben.

Bij de Dajak's wordt, nadat de naam op de boven reeds vermelde wijze is bepaald, de pasgeborene bij den tweeden vader gebracht (peetoom), die hem den buik, het voorhoofd, den rug en de genitaliën met het bloed van een kip of, bij welgestelde lieden, met dat van een varken bestrijkt. Daarna neemt de vroedvrouw het kind op beide armen, neigt het driemaal ter aarde, waarna zij het driemaal boven haar hoofd heft. Vervolgens doet de tweele vader hetzelfde, waarmede de plechtigheid geeindigd is.

In Mandeling bestrijkt men het kind niet met bloed, maar wordt het met gekauwde kruiden bespogen, die de wichelaar (datoe) van te voren gewijd heeft om den.slechten invloed der booze geesten tegen te gaan. Op Bali wordt het kind door den priester met gewijd water besprenkeld, waarna hij 's hemels zegen over het kind afsmeekt. De Dajak van Noord-Borneo besmeert het voorhoofd van het kind met de asch van het stokje, dat voor het orakel gediend heeft (zie boven), daarna wordt het kind met water overgoten en makkt men den naam bekend. Op de Kei-eilanden plakt men na de naamgeving eenige rijstkorrels op het voorhoofd en de gewrichten van het kind, opdat het spoedig helder van hoofd en sterk van ledematen worde.

De beteekenis der bovengenoemde gebruiken is m. i. van drieërlei aard. Het vleesch leggen in den mond van het kind duidt diens thans verkregen zelfstandigheid aan (het kan eten), hetgeen dáar nog meer uitkomt, waar de priester in de Minahassa, terwijl hij den door de ouders bepaalden naam noemt, aan een jongen eene tjidako (schaamtegordel), aan een meisje eenige koralen geeft. Het van Maudeling genoemde gebruik is voorspoed wenschend; het verband tusschen rijst en lichaamsgroei ligt voor de hand. Het bestrijken met bloed heeft wellicht eene symbolische beteekenis; eene reiniging wordt bedoeld, daar waar het kind voor de naamgeving in 't openbaar in de rivier gebaad of met water overgoten wordt. Daar de moeder onrein is, moet ook de vrucht haars lichaams gereinigd worden, die eerst daarna eenen naam dragen mag. Dit openbaar baden geschiedt bij de Batak's en Kajan's, en bij de Todjo's en Toboengkoe's van Midden-Celebes, waarbij de laatstgenoemden eenige erfstukken van overleden groot- of overgrootouders 
in het badwater leggen. De Kajan's begieten het kind met water. Bij de Batak's begeeft de moeder zich met een gevolg van familieleden naar de rivier om het kind te baden.

Weren te Mandeling de bovengenoemde kruiden de booze geesten af, zoo bereikt de Karau-Batak hetzelfde door een groot mes mede naar de badplaats te nemen en een lap te verbranden. Bij het baden moet eerst het hoofd nat gemaakt worden.

Ook het scheren van het hoofdhaar, gebruikelijk op Savoe en Bali en ook, zoo al niet in verband met de naamgeving, elders bekend (Java), heeft m. i. de beteekenis eener reiniging.

Waar zulke reinigingen bekend zijn, mogen kind noch moeder zich voor dien tijd in 't openbaar vertoonen. Op Java, waar de naamgeving veel vroeger plaats heeft, zullen dan ook slechts mannen op het feest verschijnen, terwijl moeder en kind verborgen blijven. Voor den maaltijd zullen de Kjai Modin en daarna de andere gasten zich met een beetje sekar boreh bestrijken; wat dit zeggen wil, weten wij niet.

Eenige, andere gebruiken mogen hier nog eene plaats vinden, behalve die, welke door den Islam of het Christendom ontstonden, en daarom hier geene vermelding behoeven.

Het overluid bekend maken van den naam is van Mandelingers, Kajan's en de bewoners der Minahassa en Keieilanden bekend, anderen zullen dit daarentegen uit vrees voor geesten nalaten. Daarbij houdt men in Mandeling tegelijkertijd een bord met rijst, kip en garnalen boven het hoofd van het kind, terwijl een der oudste mannelijke verwanten het kind op zijne verplichtingen wijst.

De Karau Batak's en anderen achten het noodig den naam aan het kind meê te deelen. Zoo knijpt de Batak het kind zachtjes in zijn oortje en zegt: Je heet si... (zoo en zoo), het is een mooie naam, nu mag je niet onwel worden. En nu blaast men Koeningspeeksel op het hoofd van het kind. Dus ook daar weder de angst dat de naam ziekte kan aanbrengen, omdat de naam het kind als een zelfstandig wezen aan de geesten bekend maakt.

Bij de Papua's ontvangt de grootmoeder gedurende het feest bijzonder veel eten voor de zorg, die zij aan het kind besteed heeft.

Elders is de naamgeving verbonden met de officieele erkenning van het kind door den vader; reeds werd hierop gewezen. De bewoners van de Seranglao-eilanden, van Aroe en Wetar laten het niet bij woorden, want de vader plant eenen boom, om zijne erkenning van het kind te doen blijken. 
Een eigenaardig gebruik moet nog van Timor vermeld worden, dat ten doel schijnt te hebben de booze geesten af te weren, zooals vele eilanders het kind voor geesten veilig achten zoolang het geenen of een slechten naam heeft. Op Timor namelijk komen op een der veertig dagen, die de moeder in huis moet doorbrengen, op verzoek van den vader, de wederzijdsche familieleden bijeen om den dag voor de naamgeving te bepalen. Vijf dagen na den dag, warop het kind eenen naam ontving, volgt het feest. Tevens wordt bij deze familievergadering bepaald, wat elk voor het feest zal bijdragen in rijst en varkens. Karbouwen mogen bij die gelegeuheid niet gegeten worden, die zijn pe mali. Op den dag der naamgeving komen vijf vrouwen, bloedverwanten van den vader in het huis, waar moeder en kind liggen en koken daar rijst in eeuen kleinen aarden pot. Met die rijst gaan zij daarna op de bale-bale zitten naast de jonge moeder en scheppen die rijst op een niroe (gevlochten, platte mand), nu eten zij de rijst met hunne handen zonder zout. of toespijzen, want die zijn bij deze gelegenheid pemali. Gedurende het eten mogen zij slechts fluisterend spreken. Als de niroe leeg gegeten is, drukken zij allen met de handen in de niroe. Een der vrouwen neemt daarna den houten lepel waarmede men de rijst opgeschept heeft en krast vijfmaal met den lepel, in de leege niroe, waarna zij den lepel ophangt. $\mathrm{Nu}$ wordt ook de niroe opgehangen en stampen de vijf vrouwen eenmaal met den voet en op het geluid van dat stampen vallen allen in met dezen zang: Ho he kore ${ }^{1}$, ko ko hare ${ }^{2}$ koreh moroh moroh (gele tabak), ko ko hare; manoes manoes sah maroh maamoeït (er is sirih, maar er ontbreekt tabak) ko ko hare. Deze panton ziet op de huwelijksgift (beli), die gegeven moet worden voor jongens en ontvangen voor meisjes.

Nadat zij vijf maal deze pauton gezongen hebben, ontvangt het kind eenen naam door den vader. Daarna wordt eene lans gebonden aan een der palen van het huis en worden vijf geweerschoten gelost tot teeken dat over vijf dagen feest zal zijn; gedurende deze vijf dagen mag het kind ook in huis niet rondgedragen worden. Voor dit feest begint wordt de pemali opgeheven door een offer aan de nitoe-nitoe te brengen en aan Oesi nenno. Is er een jongen geboren, dan moeten de vrouwen op den feestdag het haar opmaken

1 Dit zijn voorafgaande of navolgende welluidendheidsklanken evenals „hong poekolon" op Java.

"Als "ho he kore" aanmerking boven. 
zooals bij mannen gebruikelijk is, zij bezingen in pantons den lof van het pasgeboren kind. In Mandeling wordt het kind na het bad met bedak ingesmeerd, daarna houdt de moeder het kind vast en de datoe houdt een doelang met eeu grooten hoop rijst, die op bijzondere wijze is toebereid, boven het hoofd van het kind, roept onder het besprenkelen met water driemaal den levensgeest (tondi) van den jongen wereldburger aan en deelt dan mede dat het kind den door den vader bepaalden naam dragen zal, waarmede hij het geluk wenscht.

Eigenaardig is, dat op sommige eilanden het feest der naangeving met dat der eerste aanraking der aarde gecombineerd wordt, welk laatste op Java afzonderlijk gevierd wordt. Deze combinatie treft men in het oostelijk deel van den Archipel, vooral op de Kei-eilanden aan; de détails zijn in het werk van Pleyte te vinden. Ik zie in de aanraking der aarde, die natuurlijk lijdelijk plaats heeft, mede een teeken, waardoor de verheffing van het kind tot een zelfstandig wezen wordt uitgedrukt.

$W_{i j}$ naderen thans een zeer gewichtig gebruik namelijk:

Het a anemen van den nam van het kind door de o uders ( $\mathrm{K}$ aran anaq). Dit gebruik is bijna over den geheelen Archipel verbreid. Wilken wijdde er reeds eene studie aan. Evenwel meen ik het nogmaals te moeten behandelen, niet alleen omdat sedert vele nieuwe feiten bekend werden, maar vooral om reden ik overtuigd ben dat Wilken op een dwaalspoor geraakte, toen hij de hem bekende feiten verklaren wilde.

Het Karan anaq is van de volgende volkeren en eilanden bekend.

Toradja's van Centraal-Celebes en Parigi, de Alfoeren van Gorontalo, der Minahassa en der Molukken.

De bewoners van Ceram, der Kei-eilanden, der Soela-eilanden, van den Babar-archipel, van Kisar en Wetar.

De lieden van Loehoe, Gowa, de Boegi's en Makassaren, de bewoners van Savoe, Soembawa en Timor.

De Javanen, Tenggereezen, Badoej's en Balineezen.

De Dajak's en andere stammen van Borneo.

De Karau-Batak's en de Batak's van het Paneh- en Bilastroomgebied, de inboorlingen van Nias en Engano, de bewoners der Pasoemahlanden, der Padangsche Boven- en Benedenlanden, en de Redjangers.

Het gebruik wordt ook gevonden op de Philippijnen, Malakka en Madagaskar.

Slechts enkele stammen kunnen wij daar tegenover stellen, die dit gebruik niet kennen. Dit zijn de bewoners van Talauer, de 
Papua's van Noefoer, de Arfakkers, verder de Rotineezen. Bij de Toradja's van Centraal-Celebes is het ook volstrekt geen regel, meer eene veel gevolgde gewoonte. Het is wel vreemd dat de Tomori (Centraal-Celebes), wier zeden en gewoonten zooveel overeenkomst toonen met die der Toradja's, het Karan anaq volstrekt uiet kennen. Ook op het eiland Boeroe schijnt men het niet aan te treffen.

De ouders noemen zich dus: "vader van a, of moeder van a," waarbij het woord vader of moeder voor of achter deu naam van het kind geplaatst kan worden.

Voor "vader" en "moeder" worden de volgende woorden gebruikt.

Minahassa. . . . . Si ama ni (De rader van). Si ina ni (De moeder van).

Babar . . . . . . . umlee

Kisar, Wetar . . . aman

Kei. . . . . . . . ejamam

Aroe . . . . . . . oema

Savoe . . . . . . ama

Tanetteija in Binâuwe (Ma- ) oewa sâttoe of kassaren) . . . .' mangge of bapa

Boegineezen . . . . . to (vantau) da of indo

Makassaren . . . . . mangge

Badoejs . . . . . ajah ambo

Javanen en (Tenggereezen) pak (van bapak) bok (van embok).

Oud Javaansch . . . . rama

Balineezen . . . . pan of nanang

Batak (volgens Wijngaar- pa den).

Batak (volgens v. d. Tuuk) $\begin{aligned} & \text { opa ni } \\ & \text { pan of } \\ & \text { ama ni }\end{aligned}$

Maleiers der Padangsche bovenlanden . . . pa (bapa)

Dajak . . . . . . bapa

Dajak van Serawak . . pa

Dajak van Sirambau (volgens St. John) . . . ma

Nias . . . . . . ama

Engano . . . . . . ama

Pasoemah. . . . . pa

$6^{\circ}$ Volgr. VIII. rile (achter den naam) ina " " "

renan " "

djina

ina

ammá

ramani

mèn (ménèn van mémé) nandei of amei (in de doesoen)

ina ni of $\{$ al naar de nan, of beginletter na'i der namen

ma

indoe

ma (van ama)

nu

ina

ma 
De ouders noemen zich meestal naar het eerste kind en blijven diens naam voeren, hoeveel andere kinderen er ook mogen volgen; wij kennen evenwel eenige uitzonderingen op dezen regel.

De Toradja's noemen zich later dikwijls naar een jonger kind om zelf jonger te schijnen. Is het eerste kind van den Batak een meisje, dan noemt hij zich naar den oudsten zoon. De Niasser daarentegen noemt zich steeds naar den jongsten zoon en, zoo hij geen zoon heeft, dan naar de jongste dochter.

$\mathrm{Bij}$ de andere volkeren, waarbij de ouders den naam van het oudste kind voeren, blijven zij dikwijls dien naam behouden al is het kind overleden (T'enggereezen), vooral als geen ander kind volgde (Javanen), of zij nemen hun eigen naam weer aan om zich later naar het tweede kind te noemen, of zij noemen zich bij het overlijden van het eerste kind naar het tweede, als dit reeds geboren was (Oost-Java, Tenggereezen, Savoeneezen, Dajaks van Serawak). Op Engano en in de Pasoemahlanden neemt slechts de vader den naam van het kind aan, tooh kout hot ook doar moer voor, dat men bij wijze van beleefdheid ook de moeder als "ma si ano" aanspreekt, het is evenwel volstrekt geen vaststaand gebruik. Het wordt trouwens ook van de stammen uit Noord-Borneo (Serawak) gemeld, dat het noemen der ouders naar de kinderen bepaaldelijk uit beleefdheid geschiedt, zoodat de moeder slechts door de haar wel bekende, bevriende dorpgenooten bij haar eigen naam wordt genoemd. Bij de Papua's, die zich niet naar hun kinderen noemen, krijgt de moeder na de geboorte van het eerste kind den eeretitel "insos."

Daar de kinderen van den Savoenees het eigendom van de familie der vrouw zijn, zoolang hij den bruidschat (wěli) niet betaald heeft, zoo mag de vader vóór deze afbetaling zich ook niet naar zijn kind noemen.

Bij de Batak's uit het Paneh- en Bilahstroomgebied worden de ouders, zoolang het kind nog geen naam heeft "vader van een zoon (dochter) en moeder van een zoon (dochter)" genoemd.

Het is algemeen bekend dat Wilken dit gebruik door de veronderstelling verklaarde, dat de vrouw vroeger communaal bezit was en de vader daarom geen aanverwant van het kind kon zijn, dat slechts der moeder toebehoorde, zooals er dan ook heden nog volkeren gevonden worden waar de kinderen uitslnitend naar de moeder genoemd worden. Het is evenwel nog eene onbeantwoorde vraag of dit een oorspronkelijk gebruik of een gevolg van zedelijken achteruitgang is. Natuurlijke kinderen worden ook op Savoe 
naar de moeder genoemd, op Porto-Rico geschiedt dit geregeld onder de mestiezen voor alle kinderen, maar het is of een gevolg van eene overtreding der wetten (Savoe) of van demoralisatie van het volk (Porto-Rico). Wilken kwam tot zijne veronderstelling door den invloed der evolutieleer: aan het individueele huwelijk moest volgens deze wel een toestand voorafgegaan zijn, die communaal huwelijk, onder de dieren gebruikelijk, genoemd werd. Het is evenwel nog ver van bewezen dat het huwelijk, zooals wij het thans kennen, zich uit een zg. communaal huwelijk ontwikkeld moet hebben; andere ethnologen, zooals Ratzel, ontkennen zulks ten stelligste. Wilken bouwde zijne gevolgtrekkingen op dien hypothetischen grondslag op; op het communale huwelijk moest nu een toestand volgen van individueel huwelijk, waarbij evenwel de vrouwelijke verwantschap vooreerst bleef overwegen in het erfrecht, de kinderen dus niet van den vader erfden. In dit overgangsstadium moest nu de vader trachten zijn vaderschap te proclameeren, en dit kon hij niet beter doen, dan door zich, naar zijn kind, te noemen "vader van dat kind". Deze veronderstelling is al even hypothetisch als de eerste, want het is door niets bewezen dat het matriarchaat (het $2^{\text {de }}$ stadium van Wilken) ouder is dan het patriarchaat. Dit daargelaten, is het van veel meer gewicht dat ons feiten bekend zijn, die tegen deze opvatting strijden.

Ten eerste het feit: dat bij de meeste volkeren ook de moeder naar het kind genoemd wordt. Wilken erkende dit bezwaar, maar nam aan dat later, toen de oorspronkelijke beteekenis geheel verloren was gegaan, het gebruik om zich naar het kind te noemen ook op de moeder werd toegepast. Daarentegen hebben wij boven gezien dat bij de Dajak's het zich noemen naar het kind meer eene beleefdheidsphrase is ' en dit doet veronderstellen dat het eene eer is, nakomelingschap te hebben. De voorkeur, dien velen er aan geven, zich naar een zoon te noemen doet eveneens aan eene dergelijke opvatting denken, daar het meer eer is zoons dan dochters te hebben (een bijna bij alle menschen bestaande opvatting). Rationeel zou het trouwens bij de opvatting van Wilken zijn, als de vader zich naar al zijne kinderen te gelijk noemde of steeds na de geboorte van een kind van nam veranderde, hetgeen

\footnotetext{
1 Hugh Low sehrijft dan ook met recht: The curious practice of sinking their own name on the birth of the first child and being afterwards denomiminated by its name with the prefix of the particle $\mathrm{Pa}$ is strongly illustrative of their family pride.
} 
alleen van Nias bekend is. Veel meer doet ook het Javaansche gebruik, oı zich naar het overleden kind te blijven noemen als geeu andere kinderen volgen, er an denken, dat het eene eer, is vader of moeder te zijn of geweest te zijn; zooals de ongehuwde dan ook overal lager geschat, gewaardeerd wordt. Daarmede is geheel in overeenstemming dat de Papua, die zich niet naar zijn kind noemt, aan de jonge moeder de.l eeretitel "insos" geeft, en dat de Savoeneesche vader de eer om zich vader te noemen niet genieten mag alvorens hij den bruidschat betaald heeft; ook de gewoonte der Batak's om de ouders "vader of moeder van het kind" te noemen zoolang het kind nog geen naam heeft. Neumann zegt dan ook van den Batak: "Elke Batak is trotsch op het bezit van kinderen en de grootste vreugde ondervindt hij, wanneer hij zijn eerste kind verwekt heeft. Hij vindt het eene schande kinderloos te zijn. Ongehuwd staat dan ook gelijk aan onmondig, een ongehuwd man heeft geen stem, is geen staatsburger." Van de Mandelingers bericht Ris: "Een man zonder kinderen wordt niet voor vol aangezien, een kind te krijgen is het grootste geluk, de grootste eer." Op Bali wordt een vrouw zonder kinderen veracht. In het kind doet een der afgestorven familieleden voor de tweede maal zijn intocht in de wereld. De-kinderlooze zal gedurende haar leven eene gescheidene zijn, na haar dood wordt zij veroordeeld duizenden jaren eene slang aan haar borst te koesteren. Het kind (de zoon) moet dan ook liefst op zijn grootvader gelijken, die in hem terugkeerde om bij de familie te blijven. Riedel schreef over de bewoners van Wetar: "Na de geboorte van een kind krijgen de ouders andere namen, omdat zij in de negari in eenen hoogeren rang zijn gekomen dan de ongehuwden of onvruchtbaren."

Alles pleit er voor dat de beteekenis van het Karan anaq deze is: men noemt zich naar zijn kind om er mee te pronken, omdat het eene eer is vader of moeder geworden te zijn; het staat dus gelijk met een eeretitel. Evenals nu bij ons een eeretitel niet door gelijkstaande familieleden en goede vrienden bij de toespraak gebruikt wordt maar slechts door hen, die ons niet nabestaan, zoo wordt ook in Midden-Sumatra en Borneo de moeder door vreemden wel naar haar kind genoemd, maar niet door haar oudere ooms en tantes (of dorpsgenooten op Borneo) die den meisjesnaam blijven gebruiken, daar zij geen eerbiedsbetuigingen verschuldigd zijn.

Deze verklaring van het Karan anaq is geheel in overeenstemming 
met het andere gebruik om zijnen naam te veranderen bij allerlei gewichtige gebeurtenissen, zoodat ook onder die volkeren, die zich niet naar hunne kinderen noemen, toch bijna niemand sterven zal met den naam, dien hij bij de geboorte ontving. ${ }^{1}$ Deze opmerking werd reeds door Wilken zelf gemaakt, maar hij staarde zich blind op zijne evolutionistische verklaring, waarin dit feit niet paste.

Hierop lettende kan men dus zeggen: de naam is als het kleed dat beantwoorden moet aan positie, stand of werkkring ${ }^{2}$; dat blijkt duidelijk zoo wij nagaan, wanneer men in Indonesië den naam verandert.

Bij de Papua's krijgt het meisje eenen nieuwen naam bij het intreden der puberteit, op Nias veranderen de kinderen ook van naam als ze den huwbaren leeftijd naderen of huwen, ze krijgen dan een mooier klinkenden naam dan de kindernaam was. Dit geldt vooral van de dochters, waarbij de naamsverandering met groote festiviteiten en meestal lang voor de huwbaarheid plaats heeft, om den schijn te vermijden dat men met zijne dochters te koop loopt.

De jongeling wordt na het huwelijk naar den Selawa genoemd. In Mandeling behouden de knapen den kindernaam tot ze door het huwelijk meerderjarig worden en ontvangen dan den eigenlijken naam; meisjes behouden den kindernaam altijd of leggen dien af als ze moeder worden (inang si N). In een ander bericht over de Mandelingers las $i k$ dat de jonge lieden onder de notabelen bij huwbaarheid eenen titel ontvangen (galar). Dien titel verliest het meisje door het huwelijk en ruilt de man tegen den titel van zijn grootvader of oudoom. Bij de Aloengers in de Lampongs nemen mannen zoowel als vrouwen bij het huwelijk eenen nieuwen naam aan, die bij bekkenslag wordt afgekondigd.

De erftitel of de bijnaam "galar" is ook in het Menangkabosche bekend, maar slechts onder de anzienlijken. Voor eenvoudige lieden wordt de galar door den naam van het kind vervangen. Daar de galar evenwel geen naam of familienaam is, wil ik hierop niet

1 Eene uitzondering vormen de Badoejs, die als zij geen kinderen krijgen, hun namen nooit zullen veranderen, en de bewoners der L Kotta en Tanah datar in Midden-Sumatra, tenzij zij penghoeloe worden. Ook de Papua's van Kaimani veranderen hunne namen nooit.

${ }^{2}$ Deze opvatting bestaat trouwens ook in Europa bij naamsverandering, adelsverheffing enz. 
nader ingaan, bijzonderheden vindt men in het werk van Van Hasselt. Ik leg er hier slechts den nadruk op, dat die galar, die eeretitel door het zich noemen naar zijn kind vervangen wordt, waardoor het "Karan anaq" dus ook de beteekenis van een eeretitel krijgt.

Onder de Batak's krijgen de jongelingen bij meerderjarigheid andere namen, die evenwel ook meer de beteekenis van titels hebben. Daarbij geldt het voor loffelijk den titel des grootvaders over te nemen, namelijk wanneer die reeds overleden is; den titel des vaders te dragen is verboden.

Ook in Bolaäng Mongondou verwisselen sommigen op later leeftijd hun naam met een mooieren, en ook de kinderen der Kajan's wijzigen hunnen naam als zij grooter worden en wel noemen zij zich naar het kind van den jongeren broeder of zuster van hun vader of moeder, en alsof deze neven of nichten hun kinderen waren met het voorvoegsel "Ma" (vader) "Nu" (moeder). Hebben de jongere broeders of zusters van de ouders geen kinderen, dan moeten zij hun kindernaam behouden tot zij zelf een kind hebben om er zich naar te noemen. Hebben daarentegen de jongere broeder of zuster der ouders kleinkinderen, dan noemt men zich naar deze met het voorvoegsel "Bai" (grootvader) "Muk" (grootmoeder). Spencer St. John voegt hieraan toe : "they are dignified by a change of name". Hier komt het al zeer sterk uit dat het Karan anak geen proclamatie van het vaderschap is, men is er trotsch op oom of tante te zijn en toont dit door naamsverandering, een trots die trouwens ook onder Europeanen niet onbekend is.

Zeer gebruikelijk is naamsverandering op Java. In Kediri en westwaarts verandert de Javaan zijnen naam na het huwelijk en wel volgens den wensch van den schoonvader, door het eerste gedeelte van diens naam over te nemen en het tweede te wijzigen (zie boven). Het wijzigen van den naam bij de geboorte van een kind is slechts bij mindere Javanen gebruikelijk (op Bali onder de soedras). Ook hieruit blijkt dat het Karan anaq gelijk staat met een titel, dien de aanzienlijken aannemen. Deze verwisselen gewoonlijk hun naam bij hun huwelijk of bij het aanvaarden eener betrekking, welke naam dan gewoonlijk uit twee kawiwoorden bestaat. Worden zij later tot een hoogeren rang bevorderd dan verwisselen ze dien naam vaak weder met een anderen, die nog voornamer klinkt, terwijl zij, wanneer zij hunnen rang verliezen, wel eens hun kindernaam weder aannemen (Wilken) om den ouden naam 
geen oneer aan te doen ${ }^{1}$. Bij den Javaan is dus nog meer dan bij andere volkeren de naam een kleed, dat met de positie verandert. Behalve het Karan anaq kent men ook nog het Karan deså, het zich noemen naar zijne geboorteplaats; ook in Europa niet onbekend.

Dit komt op Java voor bij oude eerwaardige lieden met het voorzetsel Kjahi. Zoo spreekt men van Kjahi Pånårågå en Kjahi Mådjå. Ook Niassers en Dajak's verwisselen gaarne hun naam tegen een anderen, als zij tot hooger aanzien gekomen zijn.

Uit het bovenstaande blijkt wel voldoende dat het zich noemen naar zijn kind volstrekt niet als eene proclamatie van liet vaderschap behoeft beschouwd te worden, maar geheel past in den kring van andere naamsveranderingen, die aanduiden, dat iemands positie veranderd is; en dat eens menschen positie door de geboorte van een kind verandert, dat weten wij allen uit onze omgeving en van alle andere volkeren. Wat blijft er van de meeste menschen anders over dan de herinnering aan het feit, dat ook zij aan een kind het aanzijn gaven; veel meer vermelden toch onze stamboomen ook niet: hij werd geboren, hij stierf, hij gewon kinderen.

Het veranderen der namen. Vele volkeren in onzen archipel kennen ook nog andere redenen om tot naamsverandering over te gaan, die hier vermeld dienen te worden. De voornaamste en best bekende oorzaak is "ziekte"; daaraan ligt dan de gedachte ten grondslag de booze geesten te misleiden, zoodat zij na verandering van den naam hun slachtoffer niet herkennen. Dit doen de Toradja's (ook de Toboengkoe's van Centraal-Celebes), opdat de geesten de gevangene ziel zullen loslaten, ook de Gorontaleezen, die daarbij gaarne de namen van overleden schoonouders aannemen, de Talaureezen, die meenen, dat het zieke kind zijn eigen naam niet wil hebben "hij is warm in hem." Op Halmahera verandert men den naam met hetzelfde doel meermalen, tot genezing of de dood volgt, zoo doen ook de Makassaren; de nieuwe namen herimeren dan dikwijls aan treffende gebeurtenissen gedurende de ziekte. Ook de Dajak's veranderen bij ziekte den naam der kinderen om de geesten te misleiden. Op Boeroe doet men dit niet alleen wegens ziekte maar steeds als men kwaden invloed vreest, op Java ook

1 Dit herinnert ook aan het incognito reizen van vorsten in Europa of het bedrijven van minder lofwaardig geachte handelingen onder een pseudoniem, zooals vooral bij de geslachtsvermenging met lieden uit de volksklasse door veel aanzienlijker personen geschiedt. 
bij misoogst en andere ongelukken. Veranderen zij den naam van het oudste kind wegens ziekte, dan moeten de ouders hunne namen natuurlijk ook weer in overeenstemming brengen met den nieuwen naam van het kind. Als de Karau-Batak den naam van een kind wegens ziekte verandert, dan kiest hij namen, die de tegenovergestelde beteekenis hebben van de oude, ook bij volwassenen kan dit wegens ziekte plaats hebben. De Rotineezen zullen slechts bij jonge kinderen beneden de vijf of zes jaren de namen wegens ziekte veranderen. Men verkiest dau den naam van iemand, die zoo veel jaren dood is als het kind jaren telt; het is duidelijk dat hiermede eene misleiding der geesten bedoeld wordt. In de Minahassa weet men de geesten op eene andere wijze te misleiden: men legt het zieke kind te vondeling, na vooraf met iemand afgesproken te hebben dat hij het vinden en verzorgen zal; zijn vele kinderen gestorven dan legt men ook een volgend kind te vondeling en noemt het dan ook "vondeling".

De Makassaren veranderen wel eens hunne namen na den dood der ouders om dezer namen te dragen en deze hierdoor aan de vergetelheid te ontrukken. De Rotineezen veranderen ook den naam van een kind, dat na de geboorte voortdurend schreit, men beproeft dan eenen anderen naam der voorouders te geven, omdat men meent dat het kind den eerstgegeven naam niet hebben wil. Blijft het huilen, dan is dit een teeken dat het kind naar een der nog levende bloedverwanten genoemd wil worden. Ook de Papua's van Mansinam veranderen hunne namen dikwijls, dit gaat gepaard met festiviteiten; eene verklaring, waarom zij zulks doen, willen zij evenwel niet geven en antwoorden slechts met het woord "hadat".

Evenmin weet men waarom de Enganees zijnen naam verandert, maar Oudemans beweert dat, zoo hij zulks doet, hij den naam van zijnen hond aanneemt. Andere Papua's, die van Kaimani, veranderen daarentegen hunne namen nooit; daartegenover, als een ander uiterste, staan de Toradja's, bij welk volk bijna ieder kind een tweeden naam heeft (pompeindo), doordien men het als neef van $X$. of nicht $\operatorname{van} X$. door Ta of Tete voor den naam $X$. te plaatsen aanspreekt ${ }^{1}$. Daar nu de ouders naar hunne kinderen genoemd worden, zoo wordt dus bijna niemand bij zijn eigen naam aangesproken en behouden kinderen dikwijls hun pompeindo met

1 Ook bij de Papuas van Kaiser Wilhelmland heeft iedereen een tweeden naam (gur); zij schijnen dien eerst aan te nemen als zij volwassen zijn. Anderen noemen hen bij dien naam, zij zelf mogen hem niet uitspreken. 
het voorvoegsel Ta of Tete ook al krijgen zij later zelf kinderen. Bij vrouwen is de pompeindo of tweede naam niet zoo algemeen in gebruik, men ziet er althans niets in, om eene vrouw bij haar eigen naam toe te spreken. Kruijt, die deze gebruiken het eerst bekend maakte, voegde er aan toe, dat hij uit zijne gesprekken met de Toradja's den indruk kreeg dat de pompeindo dezelfde beteekenis als de oogsttaal der Toradja's heeft. Evenals men meent dat de geesten de gesprekken der menschen in de oogsttaal niet verstaan ${ }^{1}$ en dus in deze gesprekken geen anleiding kunnen vinden om den oogst te bederven, zoo mag men ook zijn eigen naam niet noemen en deze mag niet genoemd worden, opdat de aandacht der booze geesten niet op dien persoon gevestigd worde. Eene dergelijke oogsttaal is trouwens ook bij de Kajan's bekend (Furness). Men noemt op jacht nooit de namen der dingen, die men tracht te verkrijgen. Zoekt men kamfer dan duidt men dien bijv. aan als "het ding dat riekt" ${ }^{2}$.

Bij de boven reeds besproken verklaring, die Wilken voor het Karan anaq gaf, maakt Kruijt de volgende opmerkingen : "Over het geheel genomen komt mij de verklaring van den oorsprong van dezen tweeden naam, zooals Prof. Wilken die geeft (het zij met bescheidenheid gezegd) vreemd voor Ik kan niet anders denken, of de primitiefste vorm van samenleving was, dat ò jongeling en meisje met elkander afspraken als man en vrouw te leven, ò dat deze samenleving door de ouders bepaald werd, zooals nog hier te Poso. In beide gevallen weet het gansche dorp, wie met N. N. als vrouw leeft, en dus behoeft de man bij eventueele geboorte van een kind zijn vaderschap niet te proclameeren. Wanneer men zich het primitieve huwelijk als een soort van vrije liefde voorstelt, dan zou zich meer dan één man als vader van het kind kunnen proclameeren. Opmerking verdient nog, dat slaven in de meeste gevallen hunnen eigen naam behouden, omdat het bij die lagere wezens, naar de gedachte der Alfoeren, er niet nauw op aan komt en het niet zoo erg is, als zij door booze geesten bezocht worden. Moest de pompeindo dienen om het vaderschap te proclameeren, dan zouden ongetwijfeld ook alle slaven, die kinderen hebben, naar hun kind worden genoemd. Wanneer voorts de pompeindo

${ }^{1}$ Dus een soort „dieventaal", zou men het bij vergelijking met Europa kunnen noemen.

${ }^{2}$ Ook de Karan Bataks hebben eene oogsttaal (bij het kamferzoeken) ook de Sangireezen (zeeterm, sasahara), de Dajak's en anderen. 
alleen diende om zich als vader van het kind kenbaar te maken, zou men dan ook niet meer haast maken met het geven van eenen naam aan het kind, terwijl toch bij alle volken van den Archipel eenige dagen over de geboorte heengaan, aleer op eenen naam wordt gezonnen. Te Poso makt men er opvallend weinig haast meê, en het is streng "kapali" om over den naam van het kind te spreken, voordat het geboren is."

Deze opmerking van Kruijt kan ik slechts overnemen en er nog op wijzen dat er geheel andere middelen toegepast worden om het vaderschap te proclameeren, die wij reeds hebben leeren kennen.

Toch geloof $\mathrm{ik}$, dat men niet mag aannemen, dat het zich noemen naar zijn kind overal verklaard kan worden als eene poging om de geesten te misleiden, zooals Kruijt genegen is te doen, al wil ik gaarne aannemen dat dit door de Toradja's thans in dien zin wordt opgevat. Want door zulks te doen zou men de aandacht der geesten op het kind vestigen, en aangenomen dat de Toradja niet in dien zin redeneert, zoo acht ik de boven gegeven verklaring, die op alle soorten naamsverandering bij alle volkeren van den archipel past, voor veel natuurlijker. Ook is de vrees voor het noemen van zijn eigen naam lang niet zoo algemeen verspreid als het gebruik om zich naar zijn kind te noemen.

Laten wij dus ook nog nagaan waar de vrees voor het noemen van namen bestaat.

Verboden namen.

De volgende namen zijn kapali ${ }^{1}$.

Centraal-Celebes (Toradja).

Ouders, grootouders en andere nabestaande bloedverwanten, vooral schoonouders, van een overleden kaboesoenja (hoofd) en van het nog niet geboren kind.

Celebes ('Toboengkoe).

Schoonouders, en naaste bloedverwanten der schoonouders. Celebes (Tomori).

Schoonouders.

Celebes (Parigi).

Zie Toradja. Vooral schoonouders en aangehuwde familieleden. Halmahera.

Schoonouders en jonge kinderen.

\footnotetext{
1 Voor kapali zegt men op andere plaatsen in den archipel. kemali, pali, pamali, pèmali, kasipalli, saäli, sasi. tabu, poso, posan, pòtò, poton.
} 
Noord Halmahera (Galelareezen).

Oudere leden der aangehuwde familie.

Boeroe.

Ouders, grootouders, schoonouders, oudere broeders, ook hooggeplaatsteu.

Minahassa.

Schoonouders.

Balaäng Mongondou.

Ouders, schoonouders, oom, tante, radja. Rivieren, steenen, eilanden in de onmiddellijke nabijheid dier plaatsen '.

Luang-Sermata groep.

Schoonouders voor den schoonzoon.

Aroe.

Schoonouders en schoonkinderen wederkeerig.

Borneo (Kajan's).

Ouders, indien overleden. Een oude naam, dien men door een nieuwen verving.

Borneo (Dajak's, olo ngadjoe Dajak).

Ouders, grootouders, hunne broers en zusters en andere voorouders, levend of dood.

Soela.

Kinderen voor zij loopen kunnen, zij zouden anders sterven.

Papuá en Roti.

Namen, die men vroeger gedragen heeft.

Soemba.

Vorsten.

Bataklanden.

Ouders, ooms, tantes.

Zoover gaat de vrees voor het uitspreken dezer namen, dat men in Centraal-Celebes, op Halmahera en in de Minahassa ook in de gewone spreektaal het woord niet gebruiken mag, dat met den verboden naam overeenkomt. Heet bijv. de schoonvader "paard" dan mag men nooit meer het woord "paard" gebruiken en duidt dat dan aan door: "dier waarop gereden wordt" of "rijbeest" enz. Moet de naam des schoonvaders uitgesproken worden, dan doet men dit ò door een synoniem woord te gebruiken, òf door slechts

\footnotetext{
1 Daarnaast zoude men tal van voorbeelden kunnen plaatsen, die toonen, dat men ook vele dieren niet bij hun naam noemen mag, zoo den tijger op Java en elders. "Spreek niet van den wolf" in Europa.
} 
een gedeelte van den naam uit te spreken, of dien een weinig te veranderen, of men laat den naam door iemand anders, die tegenwoordig is, uitspreken. Vele Alfoeren vermijden zelfs de woorden, die een gelijken klank hebben met de namen hunner familiebetrekkingen vooral met den naam des schoonvaders. Heet deze dus Kalala, dan zal de schoonzoon ook het woord voor paard "Kawalo" niet mogen gebruiken.

Het is wel eigenaardig dat dit in het oosten zoo algemeen bekende gebruik in Ternate en Tidore onbekend is; evenwel zullen wij wel den daar heerschenden mohammedaanschen invloed ter verklaring mogen noemen.

Op de Aroe-eilanden noemt de schoonzoon zijne schoonouders naar den naam zijner vrouw met achtervoeging van oema (vader) of djina (moeder).

Het is moeielijk te beslissen, of deze gebruiken een soort eerbiedsbetuiging zijn of slechts aan de vrees voor de kwade geesten hun ontstaan te danken hebben. Maar al ware de laatstgenoemde oorzaak de oorspronkelijke, zoo heeft zij zich thans in elk geval met eerbied gecombineerd, daar op de meeste plaatsen slechts die namen kapali zijn, welke personen aanduiden, die aanspraak op eerbiedsbetuiging hebben. Is het noemen van namen gevaarlijk, dan zal men dat trouwens het eerst voor hen nalaten, die recht op onzen eerbied hebben, boven ons staan. Het gebruik in Insulinde heeft dan ook wel eenige overeenkomst met het algemeene Maleische, men kan ook wel zeggen Europeesche gebruik om personen van gewicht niet met hun naam maar met een titel aan te spreken. Deze titel kan aan de onderdanen of de verhouding tot de onderdanen ontleend zijn, welke verhouding met die van ouders, ooms, tantes, enz. vergeleken kan worden. Anderzijds kan de vrees voor kwade geesten van invloed geweest zijn, waarom het bij vele der genoemde volkeren ook kapali is zijn eigen naam te noemen. Vrees en eerbied zijn trouwens nauw verwante begrippen.

Kapali is de eigen naam onder de Toradja's en alle Dajak's (Kajan's, Olo-Ngadju's enz.), ook bij de Maleiers van MiddenSumatra en in Atjeh geldt het voor onkiesch naar iemands naam te vragen en zal men het ook vermijden dien te noemen ${ }^{1}$ Vraagt men zulk een naar zijn naam, dan antwoordt hij : "Vraag het $\mathrm{X}$ of $\mathrm{Y}$ ",

1 De tweede naam (gur) is ook voor den drager „kapali" in Kaiser Wilhelmland. 
die tegenwoordig is, en zoo niemand tegenwoordig is, dan doet men wel naar den naam van zijn kind te vragen en hem dan "vader van N.N." te noemen. Ook de bewoners van Bolaäng Mongondu noemen niet gaarne hun eigen namen, zij vinden het belachelijk zulks te doen en meenen zich, zoo zij het wel doen, als papegaaien te gedragen, die hun eigen naam telkens herhalen. De papegaai heet namelijk Kaleà, welk woord tevens eene nabootsing van zijn geschreeuw is. Hier is dus weer geen sprake van vrees en ik acht het niet onwaarschijnlijk dat wij ook hier slechts aan eene eerbiedsbetuiging, "achting voor zich zelf" denken moeten. Men schaamt zich zijnen eenvoudigen naam te noemen of te hooren noemen. Ook wij zouden het vreemd vinden als een vreemde ons naar den voornaam vroeg, dien een volwassen man als het ware kinderachtig vindt, - en beleedigend er meê genoemd te worden, wij hebben den familienaam als een soort titel er voor in de plaats gesteld, die aanduidt dat wij tot die en die stamgemeenschap behooren. Ik acht dit gevoel het primaire en niet de vrees, maar geloof dat de vrees er door personificatie van een gevoel bij kwam. Het is toch algemeen menschelijk een gevoel te personifieeren, en evenals de ziekte gedacht wordt in de gedaante van een kwaden geest, werd de dwang tot eerbied, dien men anderen en zich zelf schuldig is, of de bestraffing, die bij nalatigheid volgt, eveneens tot een geest, die wreekt en dien men dus vreest. Van de Niasser's en de Papua's van Kaiser Wilhelmland deelen de schrijvers dan ook mede dat zij het beleedigend achten naar hun naam gevraagd te worden, dus ook hier geen sprake van geesten, maar van gebrek aan eerbied. Ook de bewoners van het eiland Soemba zullen hun eigen naam niet noemen, maar dien door anderen laten noemen. Daar het hun tevens ongeoorloofd is de namen hunner vorsten uit te spreken, zoo noemen zij een vorst naar den naam van zijn eerst verkregen slaaf dus: Heer van N. (Oemboe lai Saroe $=$ Heer van Saroe), ook noemt men den vorst wel naar zijn landschap. Dien eerst-verkregen slaaf beschouwt de vorst dan ook als zijn "alter ego" voor wiens leven en gezondheid hij zeer bezorgd is, en die zich dan ook alles mag veroorloven. Ook hier zien wij dus weer eerbiedsbetuiging, evenals wij eerbiedig sprekende een vorst niet naar zijnen naam maar naar titel of landschap noemen. De eigenlijke naam is iets gemeenzaams, het zich noemen of genoemd worden naar landschap of kind is aan een titel gelijk te stellen en - zooals gezegd - voor de meeste menschen is het 
vaderschap de eenige titel warop zij aanspraak kunnen maken ${ }^{1}$.

$\mathrm{Op}$ Boeroe is het niet kapali den eigen naam te noemen; en dit moet ons treffen van de bewoners van een eiland, omgeven door volkeren, waar zulks wel verboden is, terwijl dit verschil niet door vreemden invloed verklaard kan worden. Het noemen der namen van oudere familieleden is daarentegen wel kapali op Boeroe. Ook de Talaureezen zien er niets in hun eigen naam te noemen, zij spotten ook met het gebruik der andere Alfoeren om zich naar hunne kinderen te noemen. Boven noemde ik reeds de Tomori, die, ofschoon zij zoo dicht bij de Toradja's wonen, zich ook niet naar hunne kinderen noemen.

Deze uitzonderingen pleiten er m.i. voor, dat namsveranderingen om welke redenen dan ook (behalve bij ziekte) meer op wellevendheid dan op bijgeloof (vrees voor geesten) berusten, want een bijgeloof (vooral zoo dit vrees wekt) is meestal veel algemeener verspreid dan een vorm van wellevendheid. De wellevendheidsvormen van Java zijn voor een groot deel specifiek Javaansch, de bijgeloovigheden der Javanen daarentegen zijn meestal aan de geheele Maleisch-Polynesische volkerengroep eigen.

Ware het "kapali-zijn" van vele namen enkel een uitvloeisel van vrees voor kwade geesten, dan zoude hiermede in strijd zijn dat men bij vele volkeren den naam van het kind met luide stem bekend maakt; dan zoude de vader zich ook niet naar zijn kind noemen en alzoo de aandacht der geesten nog meer op dit kind vestigen; ware het Karan anaq eene proklamatie van het vaderschap, dan zoude de vader steeds den naam van het kind bepalen, wat bij vele volkeren niet het geval is.

Uit bovenstaande beschouwingen blijkt overigens dat aan eene indeeling dezer volkeren in groepen volgens de hier behandelde

1 Van de Papuas (Tamo) van Kaiser Wilhelmland wordt bericht dat zij zich na hun huwelijk "Mann der Frau” noemen, dus reeds eenen titel scheppen voor het vaderschap. Dat verder de onders hunne kinderen gewoonlijk niet met hunne namen aanspreken, en de kinderen ook onderling dit niet doen, is wel een bewijs hoezeer men tracht namen te vermijden. De woorden broeder en zuster, oudere broeder, jongere broeder of zuster, dochter of zoon treden in plaats van de namen; ook kinderen van ooms en tantes worden (Sambang-Finschhafen), al naar gelang de eigen ouders jonger of ouder zijn dan oom en tante, als jongere of oudere broeder (zuster) aangesproken. Ook hier bespeurt men duidelijk een betoon van eerbied of gevoel van meerderheid. 
gebruiken niet te denken valt; dat wij dezelfde gebruiken bij ver van elkander verwijderde stammen aantreffen, waardoor eene zekere eenheid of stamverwantschap aangeduid wordt.

Maar niet alleen eene stamverwantschap van deze volkeren volgt uit deze beschouwingen, maar evenzeer eene verwantschap met de Europeesche volkeren, of in 't kort: de eenheid van oorsprong van alle menschen. Alle gebruiken zijn variatiën van eenige algemeen menschelijke opvattingen, een resultaat, dat trouwens geheel in overeenstemming is met de hedendaagsche zienswijze van yele anthropologen en ethnologen.

Alvorens te eindigen, betuig ik mijnen hartelijken dank aan allen, die mij behulpzaam waren om de gebruiken der verschillende volkeren te leeren kennen, en waardoor in deze verhandeling tal van nog onbekende gebruiken en opvattingen besproken konden worden. Vooral ben ik tot dank verplicht aan de Heeren Alb. C. Kruijt, M. J. van Baarda, K. Storm, I. L. van Hasselt, I. F. Niks en G. Maan, die mijne vragen oin inlichtingen zoo welwillend beantwoordden. Hunne namen vindt men in de Literatuuropgave terug. waardoor blijkt voor welke streken zij mij behulpzaam waren.

Utrecht, Februari 1900.

\section{LITERATU UR.}

\section{Celebes.}

Noord-Celebes, Alfoeren der Minahassa.

G. A. WrLken. Iets over de naamgeving onder de Alfoeren. Tijdschr. Bat. Gen. Dl. 22, 1875.

Holontalo.

J. G. F. RIEdel. Tijdschr. Bat. Gen. Dl. 19, 1870.

Bolaäng Mongondou.

N. P. Wilken en J. A. Schwartz. Allerlei over het land en volk van B. M.

Mededeeling van het Nederl. Zend. Gen. Dl. 18, 1871. Boewool.

J. G. F. Riedec. Het landschap Boewool. Tijdschr. Bat. Gen. Dl. $18,1871$. 
Centraal-Celebes. Alfoeren van Posso, Todjo, Gorontalo, Talaureezen, Toradjas van Parigi, Tolalaki (Kandari), Toboengkoe, Tomori.

Alb. C. Kruist. Een en ander aangaande het leven van den Posso-Alfoer. Meded. van het Nederl. Zend. Gen. Dl. 40, bl. 271 en Dl. 42 , bl. 436 .

Vele particuliere inlichtingen van den Heer KRUIJT, zendeling te Posso aan schrijver dezes.

Zuid-Celebes. Makassaren.

Volgens inlichtingen ontvangen van den Heer G. MAAN, zendeling te Tannettîya in Binâuwe.

Boegineezen, voornamelijk die van Loêwoe.

Dr. B. F. Matthes. Bijdragen tot de Ethnologie van Z.-Celebes. 1875 ; bl. 56 .

\section{Molukken.}

Boeroe.

G. A. Wilken. Bijdrage tot de kennis der Alfoeren van het eiland Boeroe. Verh. Batav. Gen. Dl. 38, 1875.

Uitvoerige inlichtingen, mij verstrekt door den Heer K. Sтокм, zendeling te Tifoe op Boeroe.

Sula-eilanden.

J. G. F. Riedel in Bijdr. Kon. Instit. $4^{\mathrm{e}}$ volgr. Dl. X., $3^{\mathrm{de}}$ stuk. Boeroe, Ambon, Serang, Seranglao-archipel. Watubela-eilanden, Kei, Aroe, Tanembar, Timorlao, Luang-sermatagroep, Babar, Kisar, Wetar , Leti-moa, Lakor en Romanggroep.

J. G. F. Riedel. De sluik- en kroesharige rassen tusschen Celebes en Papua. 's Gravenhage 1886.

Halmahera.

Dr. H. Kern. Woordenverwisseling in het Galelareesch. Bijdr. Kon. Inst. $5^{\mathrm{e}}$ volgr. Dl. V.

Particulier schrijven van den Heer M. J. van BAARDA, zendeling te Dorúme, distrikt Lolòda.

Kei-eilanden.

C. M. Plexte. Ethnographische beschrijving der Kei-eilanden. (volgens mededeelingen v. d. Heer Planten) Tijdschr. Aardr. Gen. Ser, II. Dl. 10.

\section{Nieuw-Guinea.}

Noordkust. Papoea's van Mansinam, Doreh enz.

Volgens een schrijven van den Heer I. L. vaN HASSELT, zendeling te Mansinam.

Zuid-West-kust. Papoea's van Kaimani.

Nieuw Guinea, in Bijdr. Kon. Inst. Nieuwe volgr. (1862) dee] V. 
Oostkust. Kaiser-Wilhelmland.

B. Hagen. Unter den Papua's in Deutsch Neu Guinea. Wiesbaden 1899 .

\section{Kleine Soendaeilanden.}

West-Flores (Manggarai).

I. W. Meerburg. Dagboek gehouden gedurende zijne reis door het binnenland van Manggarai. Tijdschr. Bat. Gen. Dl. 36, 1893.

Savoe.

I. WiJngaArden. Zie onder Sumatra.

Roti.

Particulier schrijven van den Heer J. F. NIKs, zendeling te Koepang.

Timor (Koepang).

Inlichtingen van den Heer Niks, bovengenoemd.

Bergstreken van Z.-W. Timor.

J. S. G. Gramberg. Eene reis in de binnenlanden van Timor. Verhand. Bat. Gen. Dl. 36, 1872, blz. 212.

Bali ${ }^{1}$.

R. van Eck. Schetsen van het eiland Bali. Tijdschr. Ned.-Ind. 1880 , blz. $411-412$.

Soemba.

Roos. Bijdrage tot de kennis van taal-, land- en volkenkunde v. h. eiland Soemba. Verh. Bat. Gen. Dl. 36 1872, bl. 70 .

Java.

Midden-Java.

C. Poensen. Iets over Javaansche naamgeving en eigennamen. Meded. Ned. Zend. Gen. Dl. 14, 1870, blz. 305.

Oost-Java.

Eigen onderzoek.

Tenggereezen (Oost-Java).

Eigen onderzoek.

Badoejs (West-Java).

Dr. Jul. JAcoBs. De Badoejs. 's Hage 1891.

\section{Borneo.}

Z. 0. Borneo (Dajaks).

M. Th. Perelaer. Ethnographische beschrijving der Dajaks, bl. 42 .

Serawak en N.-Borneo (Kajan's).

W. H. Furness. Folklore in Borneo. Pennsylvania 1899.

${ }^{1} V_{\text {AN }}$ EcK vertoefde vele jaren op Bali; op welke streek de door hem verstrekte gegevens betrekking hebben blijkt niet. 
Hugh Low. Serawak 1848, bl. 197.

Spencer St. John. Life in the forest of the far East. Dl. 1, bl. 112 en 197.

W.-Borneo (Dajak's).

Küнr. Schetsen nit Borneo's Westerafdeeling. Bijdr. Kon. Inst. $6^{\text {e }}$ volgr. deel II.

\section{Sumatra.}

Bataklanden. Karau-Batak's.

J. WisngaArden. Iets over naamgeving en eigennamen bij de Karan-Bataks. Meded. v. h. Nederl. Zend. Gen. Dl. 38, 1894 , bl. 311. Mandeling, Oeloe en Pahantan.

Heistrng. Beschrijving der onderafdeeling Groot-Mandeling en Batang-Natal. Tijdschr. Ned. Aard. Gen. S. II, Dl. 14.

Ris. De onderafdeeling Mandeling, Oeloe en Pahantan. Bijdr. Kon. Inst. $6^{\mathrm{e}}$ volgr. deel II.

Bataks Qostkust.

J. B. Neumann. Het Paneh- en Bilastroomgebied op het eiland Sumatra. Tijdschr. Aard. Gen. Ser. II, Dl. 3.

\section{Midden-Sumatra.}

A. L. van Hasselt. Volksbeschrijving van Midden-Sumatra. Leiden 1882.

Z.-Sumatra. Aboeng (Lampongs).

P. J. Veth. Tijdschr. Nederl. Aard. Gen. Serie I, Dl. 2, bl. 47. Nias.

Nieuwenhuizen en Rosenberg. Verslag omtrent het eiland Nias. Verhand. Bat. Gen. DI. 30, 1863.

Engano.

J. W ALland. Het eiland Engano. Tijdschr. Batav. Gen. Dl. 14, 1864 en Tijdschr. Nederl. Aardr. Gen. S. II, Dl. 6, bl. 144. Atjeh.

E. B. Kielstra. Onder de Atjehers, blz. 146-47. 